Sharif University of Technology
Scientia Iranica
SCIENTIA
I RAN I C A
http://scientiairanica.sharif.edu

\title{
Experimental and numerical comparison of flow and scour patterns around a single and triple bridge piers located at a 180-degree sharp bend
}

\author{
M. Asadollahi, M. Vaghefi*, and M.J. Tabibnejad Motlagh \\ Department of Civil Engineering, Persian Gulf University, Bushehr, 7516913817, Iran.
}

Received 24 November 2017; received in revised form 12 November 2018; accepted 19 January 2019

\section{KEYWORDS \\ Flow pattern; \\ Scour; \\ Bridge pier; \\ Sharp bend; \\ SSIIM model.}

\begin{abstract}
Placement of bridge piers along rivers forms a complex $3 \mathrm{D}$ flow pattern that disrupts normal river flow and the resulting turbulence erodes alluvial sediments around the pier. This study employed Sediment Simulation In Intakes with Mult-block option (SSIIM) model to simulate flow and scour patterns when no pier, single pier, and triple piers were placed at a 180-degree bend, respectively, and the results were compared with those of previous experiments. The piers were vertical. The simulated channel was $1 \mathrm{~m}$ wide with a U-turn of a relative curvature radius of 2 that carried a volumetric flow rate of $70 \mathrm{l} / \mathrm{s}$ and the flow depth at the beginning of the bend was $18 \mathrm{~cm}$. Results showed that SSIIM could effectively simulate the changes of bed form and flow patterns so that the error at the bend with triple piers would be only $4 \%$ in maximum scour and sedimentation, $12 \%$ in maximum transverse velocity, $13 \%$ in maximum longitudinal velocity, and $19 \%$ in maximum vertical velocity. In general, SSIIM model satisfactorily simulated the location and value of the local scour arising from both single and series piers in numerical simulation of the flow and scour. In the flow pattern simulation, the errors and differences are greater in the moving bed conditions than a rigid bed.
\end{abstract}

(C) 2021 Sharif University of Technology. All rights reserved.

\section{Introduction}

Flow pattern around bridge piers has a complex structure and this complexity is intensified when a scour hole around the pier is formed. Complex horseshoe vortices are formed around the pier, making a pit around them called scour hole. Development of this hole around the piers would erode sediments under the pier foundation, hence causing bridge destruction. These vortices are created due to two main factors including

\footnotetext{
*. Corresponding author.

E-mail addresses: asadollahimorteza1@gmail.com (M.

Asadollahi); vaghefi@pgu.ac.ir (M. Vaghefi);

Javad.tabib@yahoo.com (M.J. Tabibnejad Motlagh)
}

the collision of piers by the flow and separation of streamlines from the pier. The flow pattern formed around a bridge pier can be either a direct or indirect result of these two factors. The collision between the flow and pier forms the horseshoe vortex, and separation of streamlines from the pier creates vortices called wake vortices [1]. In the following, a brief summary of the related literature, though limited, is given. Nazariha investigated the scour around groups of two, three, four, and six piers placed in a flow pattern [2]. Blanckaert and Graf studied flow pattern in a 120-degree mild bend in a channel [3]. Wildhagen studied sediment transport in channels with sharp bends through the Sediment Simulation In Intakes with Multi-block option (SSIIM) numerical model and concluded that SSIIM model was widely employed in hydraulics engineering, especially in studying and 
designing sediment and flow pattern [4]. Graf and Istiarto investigated flow pattern around a scour hole at a cylindrical bridge pier placed in the rectangular straight channel [5]. Masjedi et al. studied scour around a rectangular bridge pier at different angles of a 180-degree bend. The results of their study revealed that when the bridge piers were located at a 60 -degree angle from the beginning of the bend, maximum local scour would be formed around the pier [6]. Ghobadian and Mohammadi utilized the SSIIM model to predict flow fields in non-uniform (converging and diverging) river meanders [7]. Sabita and Maiti studied a local scour around a single cylindrical pier placed in an open channel [8]. Zulhilmi et al. analyzed the local scour around both single and double piers placed in a straight channel [9]. Abdallah Mohamed et al. utilized numerical and experimental studies to investigate different effects of bridge abutment radius on the depth of local scour and employed the 3D SSIIM model to simulate scour at the bridge abutment [10]. Akib et al. simulated the extent of scour and its maximum depth around the bridge piers in nature using SSIIM2 [11]. Najafzadeh and Barani conducted an experimental study on the effect of different types of cohesive soil on the scour around a single vertical pier located in a straight channel [12]. Ehteram and Mahdavi Meymand employed the SSIIM2 model to simulate the flow and sedimentation at a bridge with a narrow reach in a $3 \mathrm{D}$ fashion [13]. Ismael et al. studied the effect of the pier shape on scour in a straight laboratory channel. They also employed ADV velocimeter to collect the flow pattern [14]. Tabarestani et al. experimentally analyzed the effect of different sizes of riprap on the scour around rectangular bridge piers in the presence/absence of a collar [15]. Azizi et al. conducted a numerical study on the flow pattern around bridge piers in the presence of submerged vanes using Fluent software [16]. Fael et al. examined the effect of the shape and angle of the pier on the scour depth around a single pier in a straight path. Generally, five types of piers were tested through these experiments. According to the obtained results in this study, the value of the shape coefficient for rectangular piers was assumed 1 with round corners and $1 / 2$ for those with sharp corners [17]. Vaghefi et al. investigated local scour formation due to a single cylindrical, yet slanted, pier. They conducted their experiments on both vertical and slanted piers placed in a clear water flow field carrying four different flow patterns [18]. They also studied scour around cylindrical bridge piers with two different diameters and slanting angles towards the downstream when clear water with different discharges flowed [19]. Wang et al. studied scour around a group of three piers in a straight channel [20]. Akbari and Vaghefi examined the flow pattern in a 180-degree sharp bend and concluded that from the beginning to the end of the bend, the secondary flow power and size of the created vortices increased [21]. Hamidi and Siadatmousavi employed SSIIM numerical model in order to conduct a numerical simulation of the flow pattern and scour around bridge piers and concluded that although the SSIIM numerical model was successful in estimating the scour hole at the foot of the adjacent piers, it overestimated the scour depth of the piers [22]. Karimi et al. carried out an experimental investigation of the effect of the inclination angle of the bridge pier on the process of scour in a straight channel [23]. Khaple et al. experimentally studied the position of grouped circular piers in a straight path under clear water conditions. The results showed that installation of two piers in a row at a distance of approximately 8 times the pier diameter from each other reduced scour depth at the pier downstream [24]. Vaghefi et al. studied the scour around a series of triple cylindrical piers in two positions, perpendicular to the flow and in streamwise direction, under clear water conditions in a laboratory flume with a 180-degree sharp bend. The results of their study revealed that the maximum scour depth was achieved when the piers were installed perpendicular to the flow at the 90-degree position [25]. The present study examines the precision and error values for the SSIIM numerical model while modeling single and series bridge piers located at a 180-degree bend and aims to show the extent of the capability of this numerical model.

\section{The numerical model}

SSIIM model is a three-dimensional model used for measuring the water flow and sediment whose first version was introduced in 1993 by Olsen from the School of Hydraulic and Environmental Engineering at Norwegian University of Science and Technology [26]. This model is based on three-dimensional computational fluid dynamics which solves Navier-Stokes Equation typically with the standard k-epsilon $(k-\varepsilon)$ turbulence model using finite volume method. Of note, the model allows users to choose other turbulence models as well. It is usually utilized for river engineering, environmental engineering, hydraulics, and sediment transport applications. Later, its utilization was extended to other hydraulic applications such as modeling weirs, head loss in tunnels, correlating discharge and depth in rivers, etc. The main advantage of the SSIIM model over other computational fluid dynamic programs is its ability to model sediment transport in a live bed with complex geometries [27].

In this numerical model, the water flow calculations include the Navier-Stokes equations solved by $k-\varepsilon$ turbulence model and used by default. The Navier-Stokes equation for incompressible fluid in the vector mode is shown in the following: 


$$
\frac{\partial u_{i}}{\partial t}+U_{j} \frac{\partial u_{i}}{\partial x_{i}}=\frac{1}{\rho} \frac{\partial}{\partial x_{i}}\left(-P \delta_{i j}-\rho \overline{u_{i} u_{j}}\right),
$$

where $U$ is the velocity averaged over the time $t, x$ is the spatial geometrical scale, $\rho$ is the water density, $P$ is the pressure, $\delta$ is the Kronecker delta, and $u$ is the velocity fluctuation over time during time step $\Delta t$.

In order to assess the last term, a turbulence model is required. In general, the equation of flow in the turbulence model comprises both continuity and momentum equations. By assuming that the flow is steady $\left(\frac{\partial}{\partial t}=0\right)$ and the fluid is incompressible, the momentum and continuity equations can be explicable in the following order:

$$
\begin{aligned}
\frac{\partial}{\partial x j}\left(\rho u_{i} u_{j}\right)= & -\frac{\partial p}{\partial x j} \delta_{i j}+\frac{\partial}{\partial x j} \mu\left(\frac{\partial u_{i}}{\partial x j}+\frac{\partial u_{j}}{\partial x j}\right) \\
& +\frac{\partial}{\partial x j}\left(-\rho \bar{u}_{i} \bar{u}_{j}\right), \\
\frac{\partial}{\partial x j}\left(\rho u_{j}\right)=0, &
\end{aligned}
$$

where $u_{i}$ and $u_{j}$ are the velocity parameters. According to the above equations, three momentum equations and one continuity equation can be written, three of which are totally unknown (velocity on three sides $u, v, w$ and six parameters for Reynolds stress), meaning that the number of unknowns is more than the number of equations and in order to solve them, the turbulence equation should be used [27].

\section{Verification of the numerical model using a similar experimental model}

The channel used in this study is located at the hydraulic laboratory at Persian Gulf University, Bushehr, Iran, which has a 180-degree bend. To simulate flow and scour pattern, several experiments were performed in an empty channel with no pier, single pier, and a series of piers at the bend, respectively [28]. The channel comprises a straight leg upstream of $6.5 \mathrm{~m}$ and a straight leg downstream of $5.1 \mathrm{~m}$ connected via a 180 -degree bend with inner and outer radii of $1.5 \mathrm{~m}$ and $2.5 \mathrm{~m}$, respectively. The depth and width of the channel are $0.7 \mathrm{~m}$ and $1 \mathrm{~m}$, respectively, and the relative curvature radius of the bend is 2 . A schematic view of the experimental flume is shown in Figure $1[29,30]$.

The longitudinal slope of the channel is 0.001 and the bed is filled up at a depth of $30 \mathrm{~cm}$ with sediments and an average diameter of $1.5 \mathrm{~mm}$, standard deviation of 1.14, and Stickler number of 62.5. The discharge rate is $70 \mathrm{l} / \mathrm{s}$ and the pier diameter for the models with single and multiple piers is $5 \mathrm{~cm}$. The present study modeled a channel similar to that implemented in an experimental study using SSIIM and compared the measured and simulated three-dimensional flow velocities and bed topography. Throughout these experiments, the Reynolds number is approximately 50000 and the ratio of flow velocity to flow critical velocity is approximately 0.98 . In order to calibrate the SSIIM model, a range of the parameters for this model were introduced to the software and after many runs, the best parameters with the closest simulation between the numerical and experimental models were selected for a bend with no piers. Then, these parameters were constantly used in other cases.

\subsection{Modelling the laboratory channel}

Prior to mathematical modeling, domain discretization of cells is required where the governing differential equations for flow and sediment fields should be solved. This process is called computational domain meshing or discretization. The channel was simulated with different mesh sizes and configurations by introducing the initial data to Koordina file in SSIIM 1.0, as shown in Table 1. Mesh sizes decreased near bridge piers in the vicinity of higher gradients. In fact, 30 different mesh sizes and configurations were utilized in designing
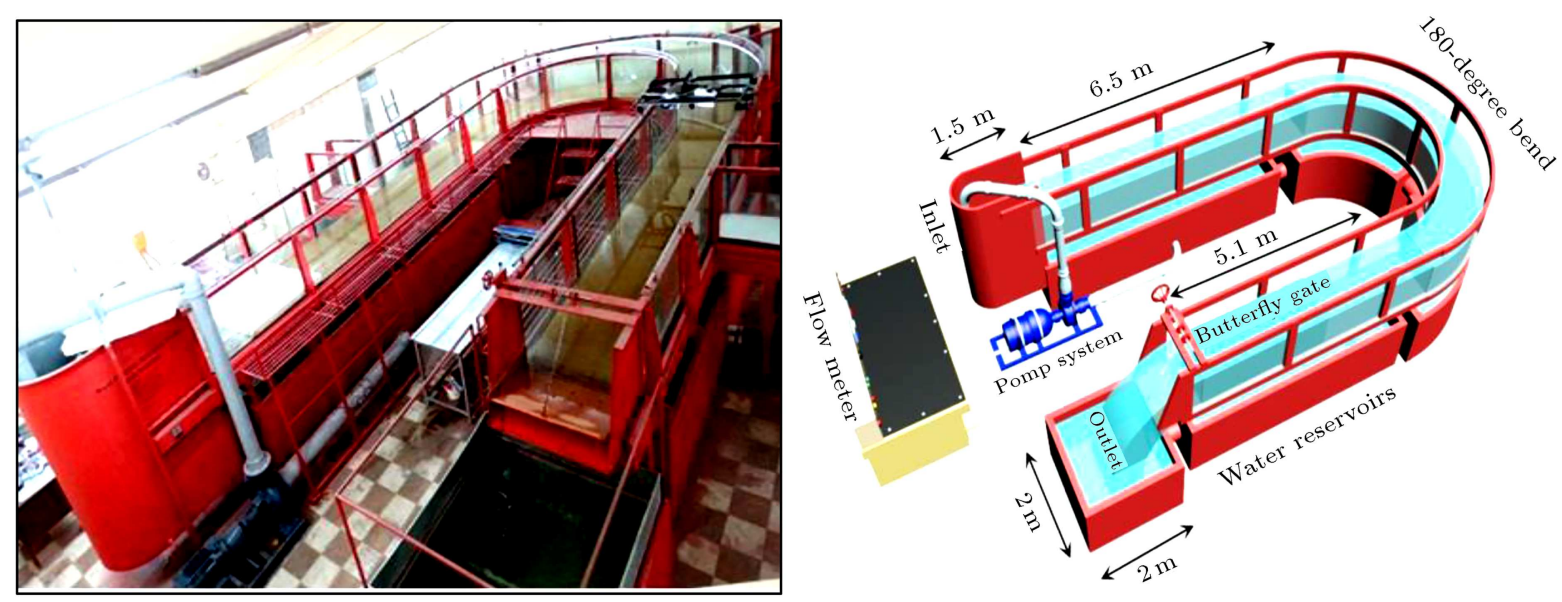

Figure 1. A view of the laboratory flume $[29,30]$. 
Table 1. A typical modeled mesh configuration for the triple bridge pier.

\begin{tabular}{ccc}
\hline Mesh number & $\begin{array}{c}\text { Number of } \\
\text { cross-sections }\end{array}$ & $\begin{array}{c}\text { Number of } \\
\text { longitudinal } \\
\text { sections }\end{array}$ \\
\hline 1 & 19 & 11 \\
2 & 37 & 21 \\
3 & 37 & 51 \\
4 & 43 & 61 \\
5 & 47 & 61 \\
6 & 75 & 35 \\
7 & 90 & 51 \\
8 & 91 & 101 \\
9 & 101 & 111 \\
10 & 101 & 127 \\
\hline
\end{tabular}

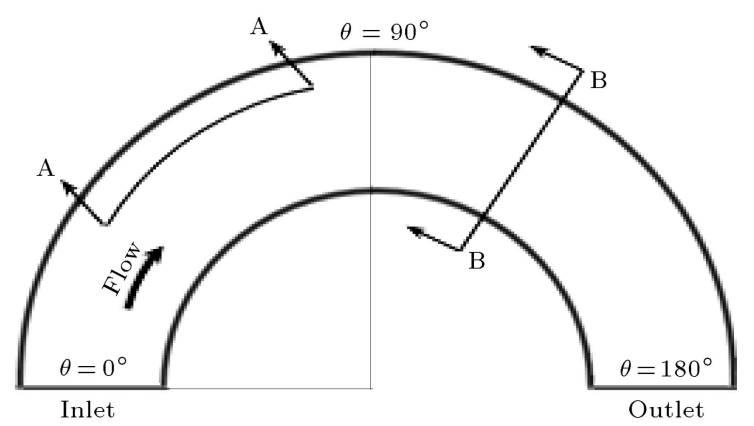

Figure 2. A schematic view of longitudinal section (A-A) and cross-sections (B-B).

the numerical model and verifications. With a decrease in the mesh size, the program runtime increased. However, the obtained results ensured higher accuracy. At times, tiny mesh sizes would cause instability and divergence in the program execution.

Upon adding the data to the control file, the program is run and results are stored in a file with the same name. Results of SSIIM runs versus those of the previous experiments are verified. It can be concluded that the mesh configuration number 5 is characterized by more accurate match and higher efficiency than other mesh configurations. Figure 2 schematically presents the longitudinal and cross-sections.

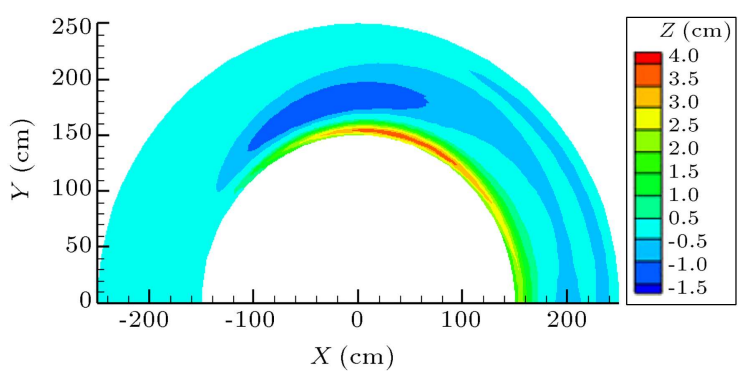

(a)

\subsection{Verification of the numerical model with the similar laboratory model at the 180-degree bend with no pier}

Figure 3 shows the bed topography in both experimental and numerical models. Flow and scour patterns were studied over a live bed, and the bed materials were glued together to ensure no movement; then, the flow pattern alone was studied. As shown in Figure 3, the scour hole in the laboratory model spans from 42 to 80 degrees and extends to $18 \%$ of the width of the channel from the inner bank. Maximum scour depth is $1.8 \mathrm{~cm}$ which is equal to 1.8 percent of the channel width. In addition, sedimentation occurs in the range of 47-96 degrees at the inner bank of the bend up to $4.3 \mathrm{~cm}$, equal to $4.3 \%$ of the channel width. However, in the numerical model, the scour hole spans from $60-105$ degrees and extends to $18 \%$ of the channel width from the inner bank. Maximum scour depth is $1.5 \mathrm{~cm}$, which is equal to $1.5 \%$ of the channel width, and sedimentation occurs in the range of 88-119 degrees at the inner bank of the bend up to $3.9 \mathrm{~cm}$, equal to $3.9 \%$ of the channel width.

Bed topography data for both numerical and the experimental models were compared, the results of which are shown in Figure 4 where the bisector line

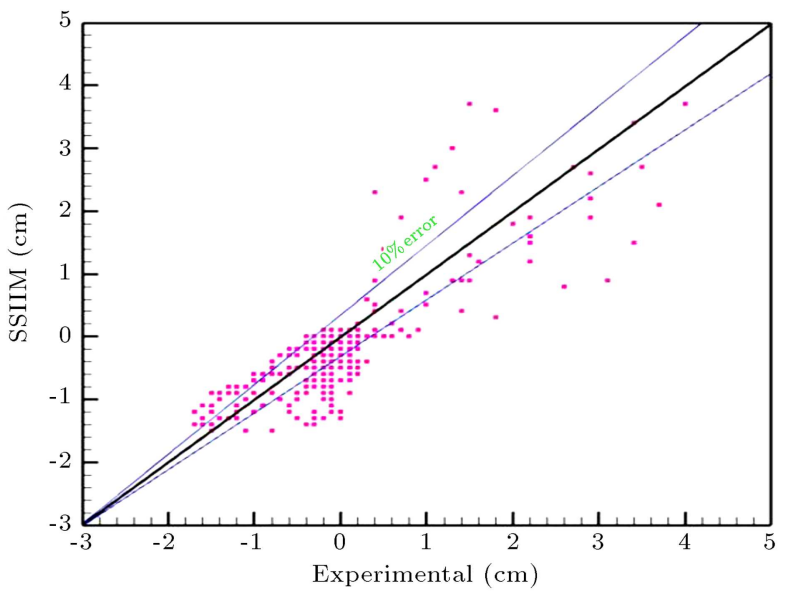

Figure 4. Comparison of bed topography data for numerical and experimental models at the bend without any pier.

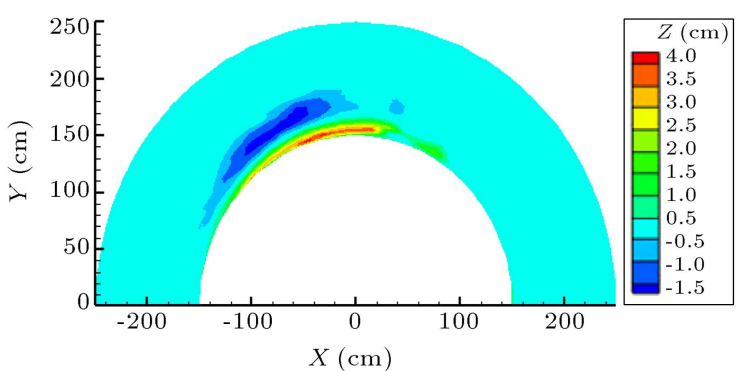

(b)

Figure 3. Bed topography at the bend without any pier: (a) Numerical and (b) laboratory models. 


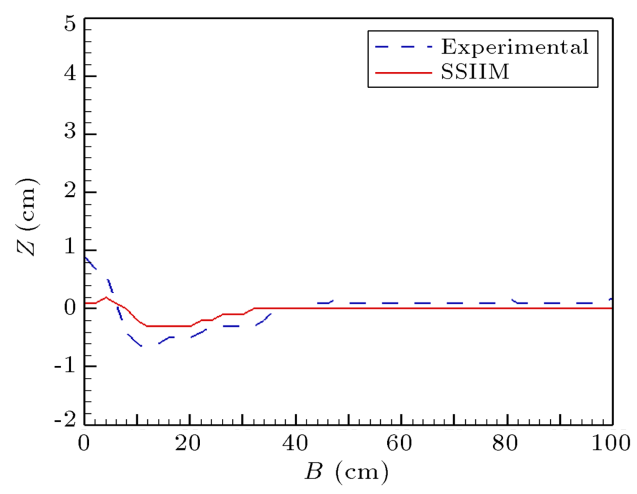

(a)

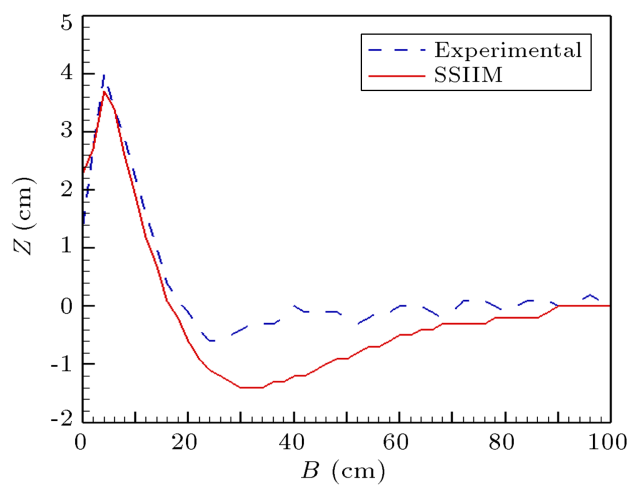

(c)

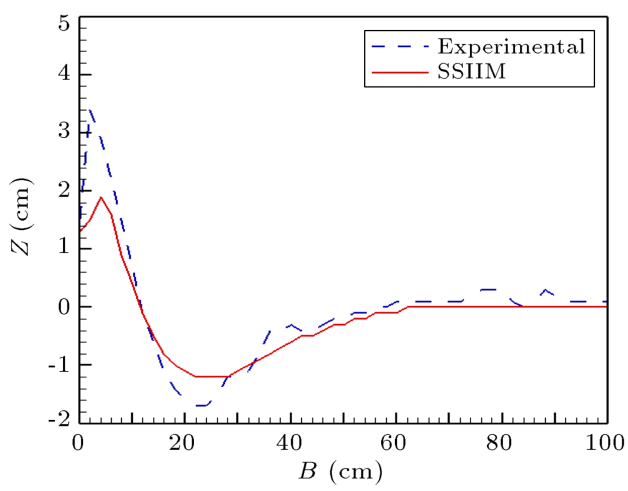

(b)

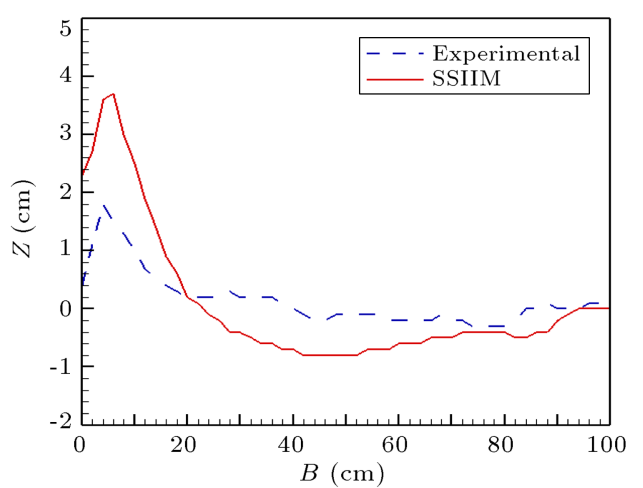

(d)

Figure 5. Typical bed cross-sectional profiles at (a) 30, (b) 60, (c) 90, and (d) 120 degrees from the channel beginning at the bend without any pier.

shows good agreement between the two with an error less than $10 \%$.

Figure 5 shows the shapes of the bed cross-section for both numerical and experimental models. The horizontal axis shows the distance from the inner side $(\mathrm{cm})$ and the vertical axis is bed variations $(\mathrm{cm})$. As shown in Figure 5(a), in the experimental model, sedimentation covers up to $8 \%$ of the channel width at the inner bank of the bend at the 30-degree crosssection. Scour occurs beyond the $8 \%$ of the width and up to $40 \%$ from the inner bank of the bend at a value of $0.7 \%$ of the channel width. Scour at the same location occupied only $0.35 \%$ of the channel width in the numerical model. In more than $40 \%$ of the width, no significant bed variation is observed. As shown in Figure 5(b), sedimentation in the experimental model occurs at the inner bank of the bend with a value equal to 0.7 times the pier diameter at the 60-degree crosssection. At $10-40 \%$ of the width from the inner bank, scour occurs at a value of the $1.5 \%$ of the channel width diameter, with the maximum scour occurring at $23 \%$ of the width from the inner bank. In the numerical model, scour occurs at the same distance and a value of $1.2 \%$ of the channel width. At $40-60 \%$ of the width from the inner bank, scour depth decreases and continues across the width with minor variation. As shown in Figure 5(c), in the 90-degree cross-section, the bed pattern is very similar to that in other cross-sections in that sedimentation, which is observed at the inner bank of the bend. In the experimental model, maximum scour depth occurred at $24 \%$ of the width from the inner bank, while this was at $30 \%$ of the width in the numerical model. From the maximum scour location to the $60 \%$ of the width from the inner bank, scour decreased and had minor variation beyond the outer bank. At the 120-degree cross-section (Figure 5(d)), both models resulted in maximum sedimentation at the inner bank of the bend. Towards the mid channel, scour initiates and maximizes at $44 \%$ of the width from the inner bank of the bend. Towards the outer bank, however, scour decreases and becomes zero at the outer bank of the bend.

Figures 6 and 7 present typical profiles for 3D velocity vectors in 60 - and 90-degree cross-sections in numerical and experimental models, respectively. The horizontal axis shows the distance from the inner bank and the vertical axis presents the elevation made dimensionless by flow depth. As the flow enters the bend, pressure decreases along the inner bank and increases along the outer bank due to rapid changes in curvature and longitudinal pressure gradient caused by the centrifugal force. Once such a trend extends into the bend, secondary currents are formed in the cross-section so that streamlines can head to the outer bank close to 

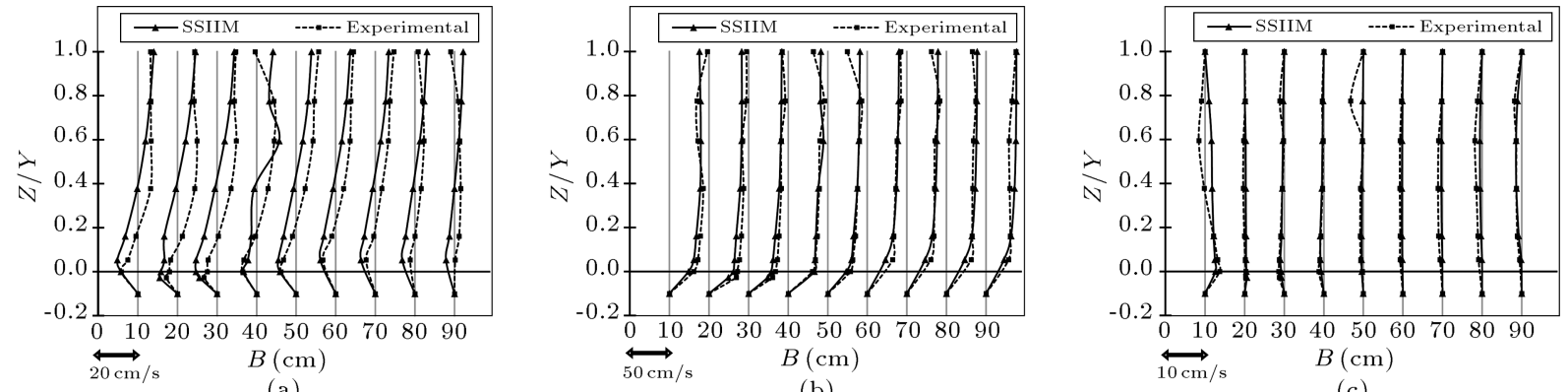

(b)

(c)

Figure 6. Typical (a) transverse, (b) longitudinal, and (c) vertical velocity profiles in the 60-degree cross-section in numerical and experimental models at the bend without any pier.

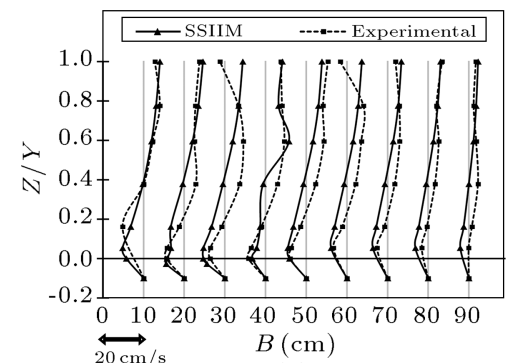

(a)

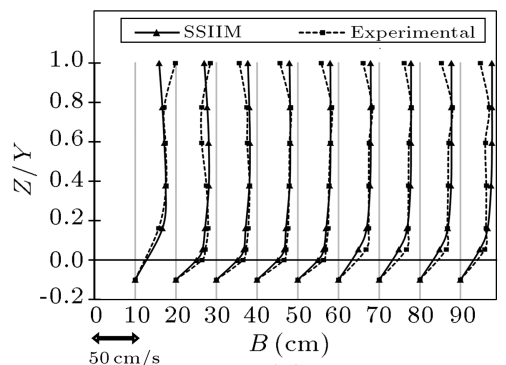

(b)

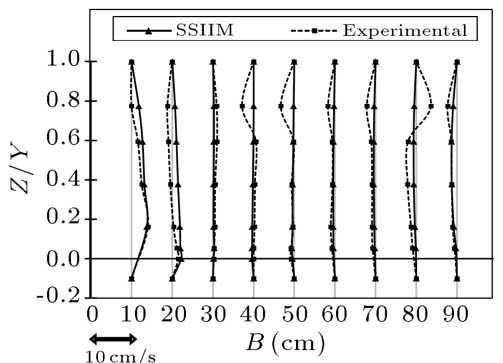

(c)

Figure 7. Typical (a) transverse, (b) longitudinal, and (c) vertical velocity profiles in the 90-degree cross-section for numerical and experimental models at the bend without any pier.

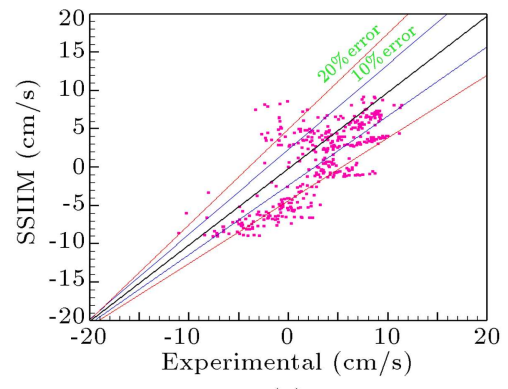

(a)

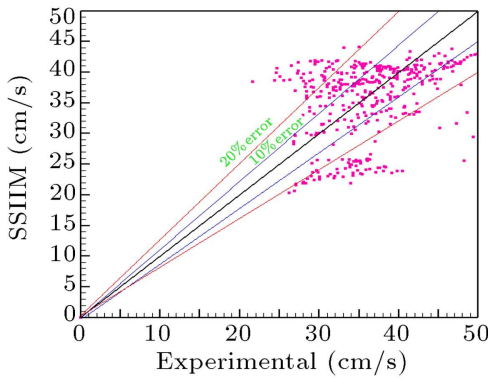

(b)

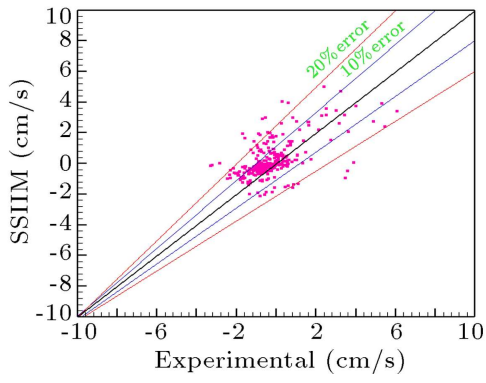

(c)

Figure 8. Comparison of (a) transverse $U_{r}$, (b) longitudinal, $V_{\theta}$, and (c) vertical, $W_{z}$, velocity data for numerical versus experimental models at the bend without any pier.

the water surface and to the inner bank near the bed. Obviously, longitudinal velocities are higher than vertical and transvers velocities and are of better match.

Figure 8 compares the 3D velocity data over the live bed in both numerical and experimental models where the bisector line shows good agreement between the two with errors less than $20 \%$.

Figure 9 presents the flow pattern in the 60degree cross-section where the maximum scour occurs. As shown, eddies are formed in both numerical and experimental models at almost the same locations. Streamlines are denser in the numerical model since mesh sizes are finer in the numerical model than that in the experimental one. Besides the main eddy near the inner bank in the experimental model, another counter clockwise eddy is formed near the water surface at the outer bank of the bend.

\subsection{Scouring verification of the numerical model using a similar experimental model at a 180-degree bend with a single pier}

In this experiment, only scour pattern was investigated over the live bed. As shown in Figure 10, numerical and experimental results are consistent in terms of scour depth and location as well as maximum sedimentation. The bridge pier is located in the middle of the channel width at the vertex. Sedimentation occurs at the inner bank of the bend due to minimum shear stress. In the experimental model, sedimentation occurs at the inner bank of 34-83 degrees with a value of 0.5 times the pier diameter. Maximum scour in both models occurs around the bridge pier at the vertex. In the experimental model, the scour depth is $17 \mathrm{~cm}$, equal to 3.4 times the pier diameter. Downstream of the pier, from 104 to 142 degrees, sedimentation 


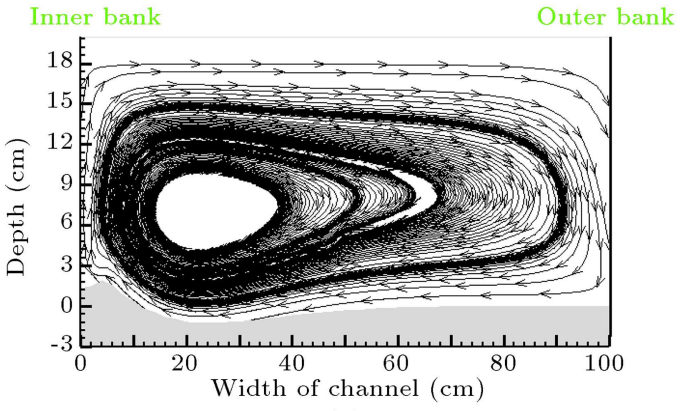

(a)

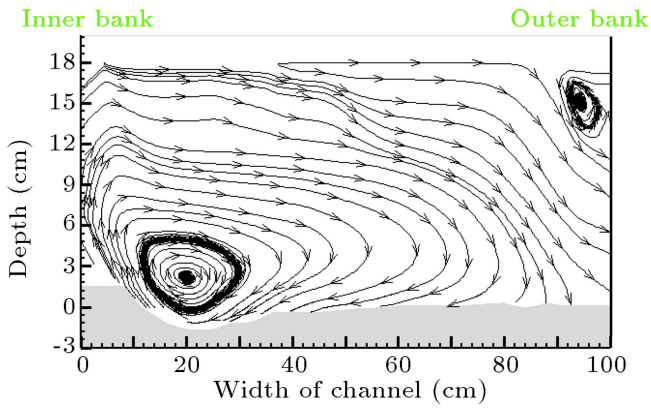

(b)

Figure 9. Typical flow pattern in the 60-degree cross-section in (a) numerical and (b) experimental models.

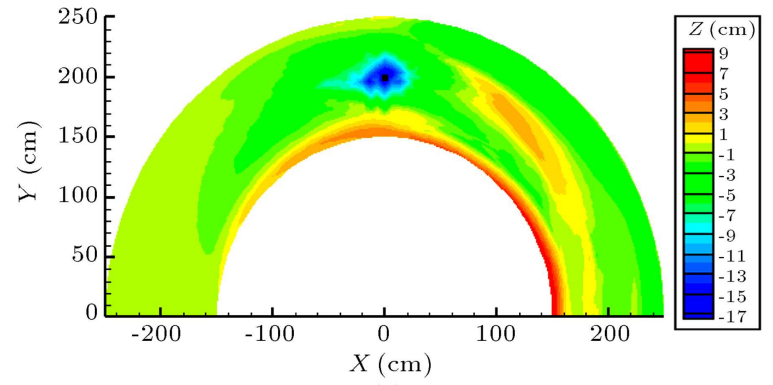

(a)

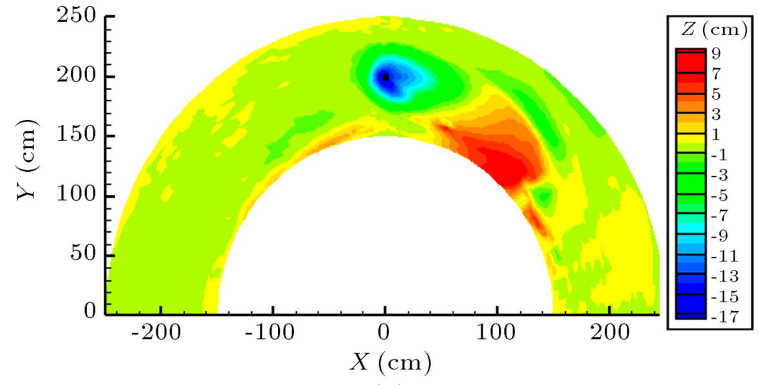

(b)

Figure 10. Bed topography in (a) numerical and (b) experimental models at the bend with a single pier.

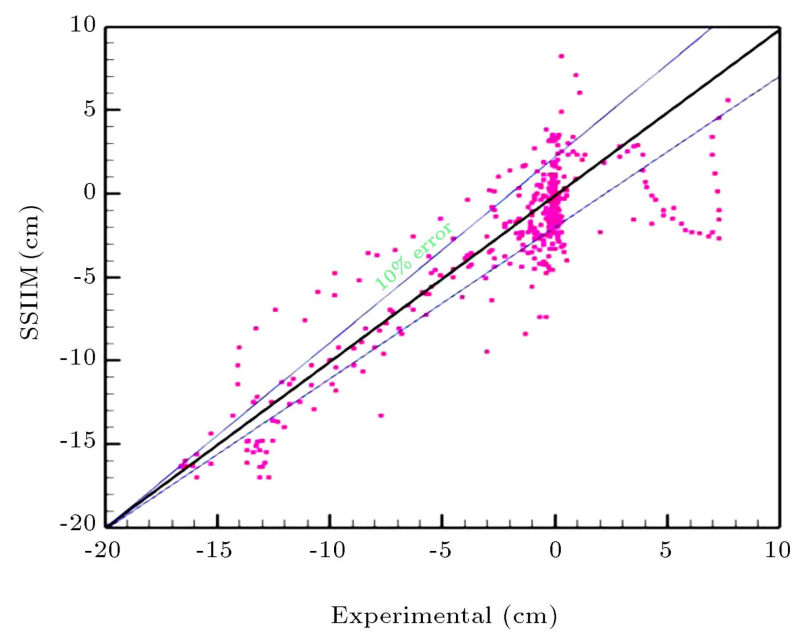

Figure 11. Comparison of bed topography data for the numerical versus experimental models at the bend with a single pier.

occurs at a depth of $9 \mathrm{~cm}$, equal to 1.8 times the pier diameter. The sedimentation extends to the depth equal to $50 \%$ of the width. In the numerical model, scour depth equals $17 \mathrm{~cm}$, equal to 3.4 times the pier diameter. Furthermore, sedimentation which started at 30 degrees on the inner side of the bend extends throughout the bend. Sedimentation in the numerical model is $9 \mathrm{~cm}$, equal to 1.8 times the pier diameter.

Bed topography data for the numerical and experimental models are compared in Figure 11, where the bisector line shows good agreement between the two with errors less than $10 \%$.

Figure 12 shows typical bed forms for four different cross-sections. At a 60-degree cross-section for both models, sedimentation is observed at the inner bank of bend and it switches to scour in a region closer to the mid channel toward the outer bank. From the mid channel outward, no significant bed variation is observed in either model. Maximum scour in both numerical and experimental models is observed at the bridge pier due to increased longitudinal velocities and formation of strong secondary flow there (Figure 12(c)). Furthermore, downstream the pier, a sedimentation mound forms in both models due to reduced velocities and sediment transport downstream from the scour hole (Figure 12(d)).

\subsection{Verification of the numerical model with a similar experimental model at a 180-degree bend with a series of bridge piers at the vertex}

The verification process for the model based on the experiments previously carried out on delineating flow pattern over a rigid bed and scour pattern over a live bed with a series of bridge piers at the vertex was conducted at the Hydraulic Laboratory of Persian Gulf University by Tabibnejad Motlagh [31]. Figure 13 shows the consistency of numerical and experimental results in terms of scour maximum depth and location and maximum sedimentation, such that maximum 


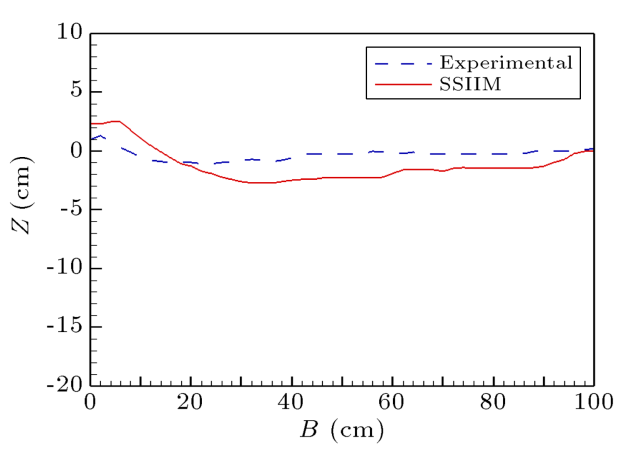

(a)

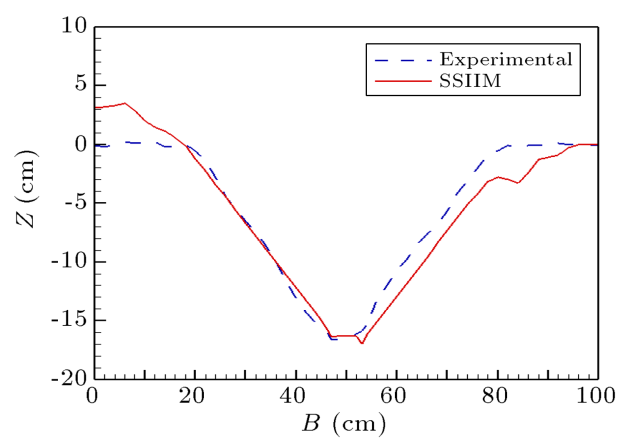

(c)

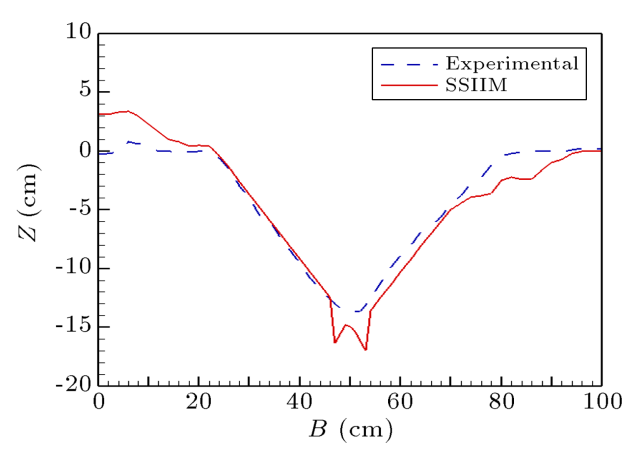

(b)

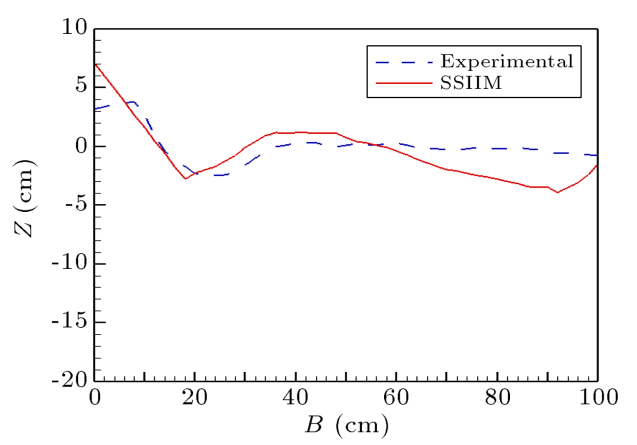

(d)

Figure 12. Typical bed cross-sectional profiles at (a) 60, (b) 88, (c) 90 , and (d) 145 degrees from the channel beginning at the bend with a single pier.

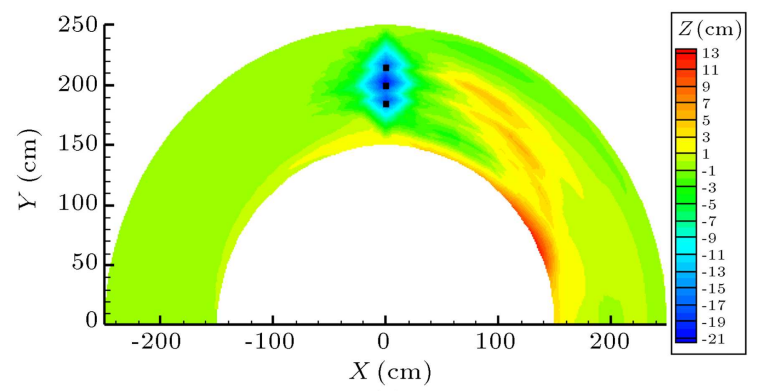

(a)

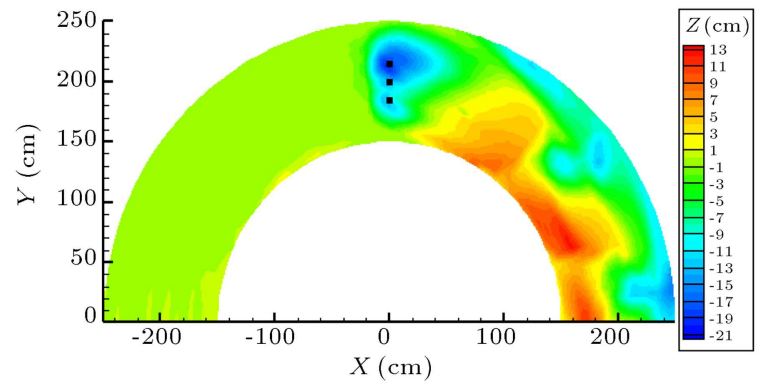

(b)

Figure 13. Bed topography in (a) numerical and (b) experimental models at the bend with a series of piers.

scour depth in the numerical model is $21 \mathrm{~cm}$, equal to 4.2 times pier diameter at 90 degrees and occurs at the $53 \%$ width distance from the inner bank of the bend. These values for the experimental model are $20 \mathrm{~cm}$, equal to 4 times the pier diameter at 90 degrees and occurs at $64 \%$ width distance from the inner bank of the bend. It is obvious that in both models, maximum scour depth occurs around piers due to transverse disturbances and formation of downward flows and different eddies there. Furthermore, sedimentation occurs at the inner bank of the bend where flow exits the bend with minimum shear stress remaining. The sedimentation mound in the numerical model was $12 \mathrm{~cm}$, equal to 2.4 times the pier diameter placed at a 155-degree angle and in the experimental model, it was $12.5 \mathrm{~cm}$, equal to 2.5 times the pier diameter placed at a 156-degree angle.
In Figure 14, bed topography data for the numerical and experimental models are compared where the bisector line shows relatively good agreement between the two with errors mainly between 10 and $20 \%$.

Figure 15 shows bed variations at some crosssections for the numerical and experimental models; maximum scour is produced at the bridge pier locations. The profiles resulting from the numerical and experimental models are in better agreement upstream of the bridge pier locations compared to their downstream. At the 60-degree cross-section, bed variation is insignificant in either model, due to the farther distance of the section from the piers. In the 90-degree crosssection, in the experimental model, scour initiates at the inner bank of the bend and reaches its maximum at $64 \%$ of the channel width. In the numerical model, on the other hand, a small sedimentation mound forms 


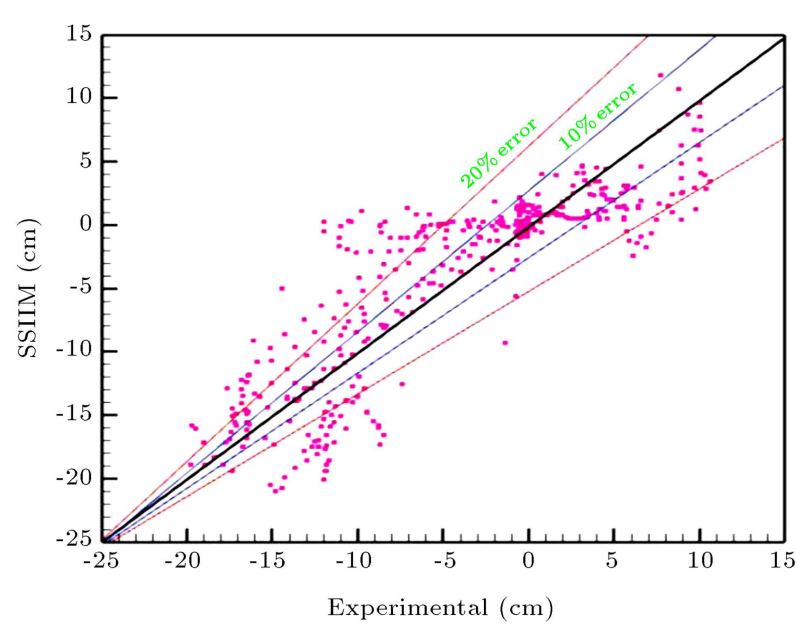

Figure 14. Comparison of bed topography data for the numerical and experimental models at the bend with a series of piers.

at the inner bank at the beginning of the bend and extends to $10 \%$ of the width. Then, scour hole is formed with maximum scour depth at $53 \%$ of the width from the inner bank of the bend. Downstream of the piers (Figure 15(d)), sedimentation at the inner bank occurs due to sediment transport from the scour hole around piers and in the experimental model, scour occurs at the outer bank due to secondary flow remaining there.

In Figures 16 and 17, verification of $3 \mathrm{D}$ velocity profiles for 60 - and 90-degree cross-sections is shown

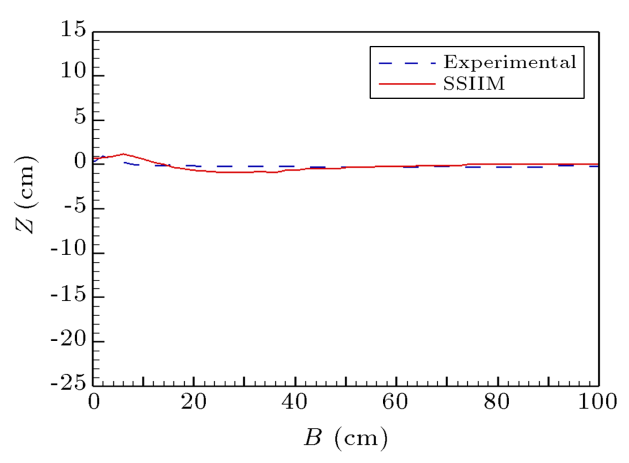

(a)

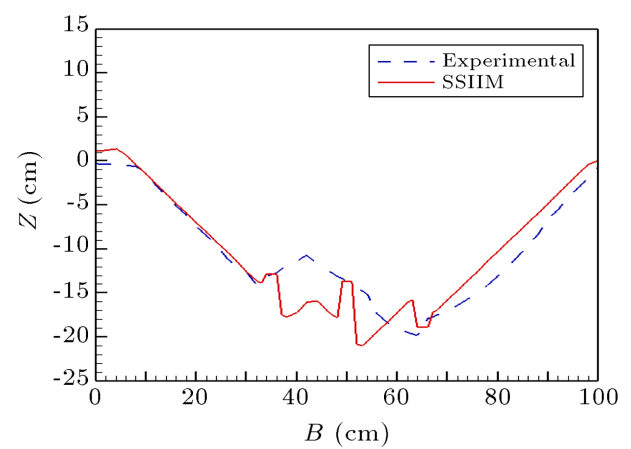

(c) with a magnification of 36 to $64 \%$ of the width from the inner bank of the bend. As shown earlier, profiles are for the solid bed and these sections have been selected to better visualize bed forms at the location of bridge piers as well as its upstream and downstream. As shown in Figure 17, all the three velocity components at $36,48,52$, and $64 \%$ of the channel width from the inner bank are zero, which is obvious due to the placement of piers there. A transverse flow towards the inner bank near the bed and an outward flow near water surface is indicative of an eddy there. This is the main eddy in what is called the secondary flow. Based on the velocity magnitudes, it is obvious that the main eddy near the inner bank has greater intensity and velocity than the eddy towards the outer bank of the bend.

In Figure 18, 3D components of the velocity data for the numerical versus experimental models are compared against one another and the bisector line shows a good approximation between the two with errors mainly between 10 and 20\%. The discrepancy in the data results mainly from the difficulties in measuring 3D velocity components in the experimental model near side walls (both at the inner and out banks) and bridge piers. The difference observed in numerical and experimental velocity data is due to the method of data collection, employment of velocimeter near the point of data collection, and use of the asynchronous average velocity in the laboratory.

In Figures 19 and 20, flow pattern in a typical

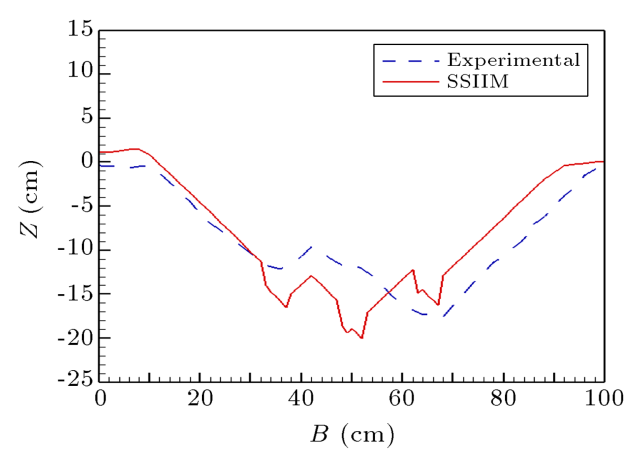

(b)

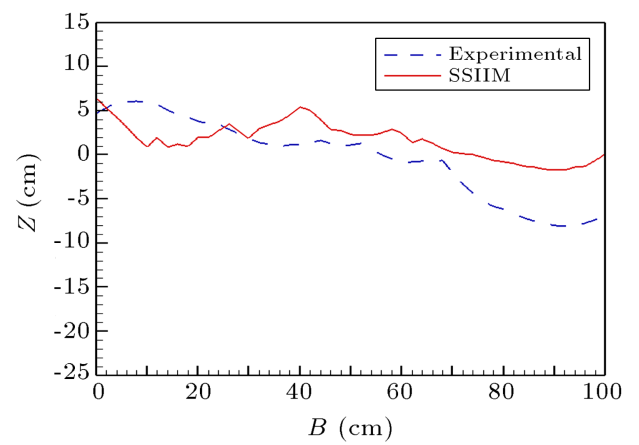

(d)

Figure 15. Typical bed cross-sectional profile at (a) 60, (b) 88, (c) 90, and (d) 130 degrees at the bend with a series of piers. 

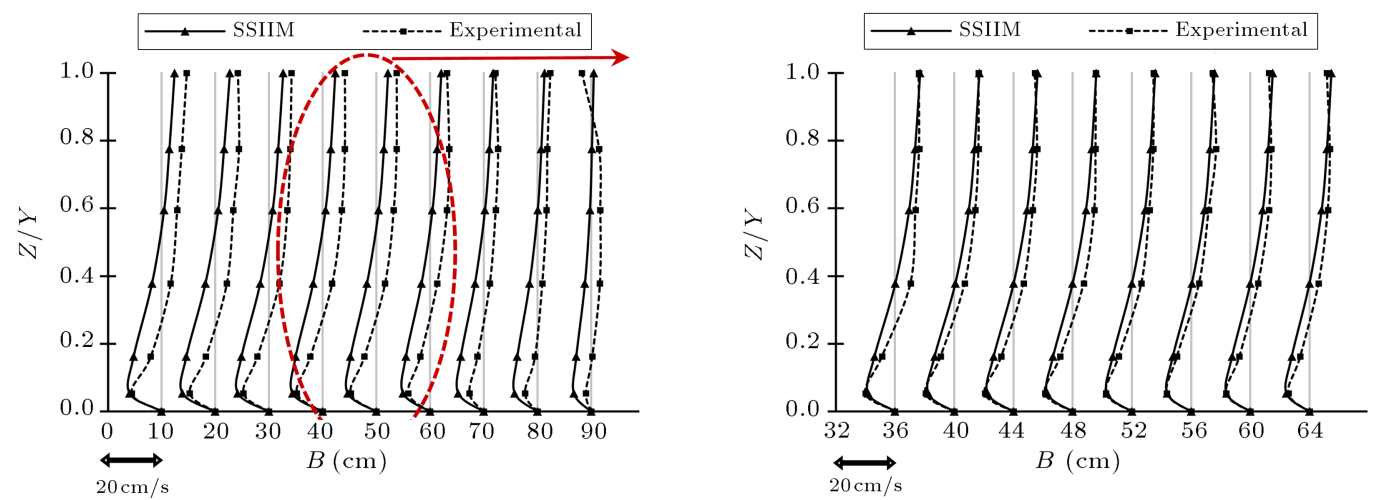

(a)
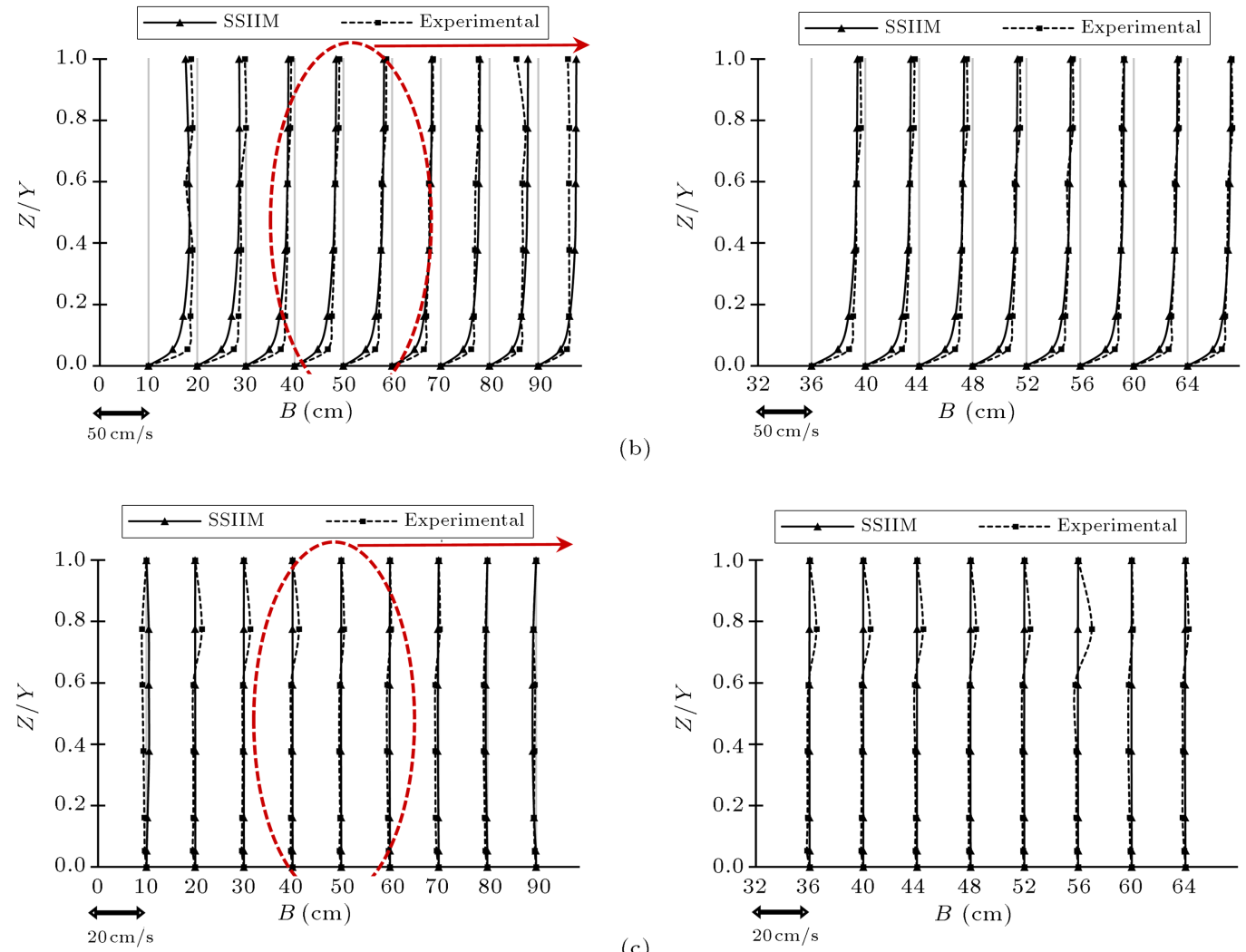

Figure 16. Typical (a) transverse, (b) longitudinal, and (c) vertical velocity profiles in the 60-degree cross-section in the numerical and experimental models at the bend with a series of piers.

cross-section is shown. From the beginning of the bend, the main secondary flow eddy is formed near the bed at the inner bank of the bend. In the 60degree cross-section, in the experimental model, near water surface and at the outer bank, a turbulence is formed in the streamlines which is the start of the second secondary flow formation. In the 88-degree cross-section at a distance of 1.4 times the pier diameter from the pier location towards upstream, as one moves towards the pier location at distances equivalent to 36 , 51 , and 65 percent of the width from the inner bank, turbulence and separation of streamlines are observable in both numerical and experimental models. In the 90- degree cross section, eddies are formed near the inner and outer banks due to secondary flow. In addition, vertically downward flows are formed in between piers which cause bed erosion in the live bed. Downstream of the piers, many eddies and turbulences are formed which dissipate at the end of the bend and normal flow continues running.

\section{Conclusion}

By simulating the experimental model with the SedimentSimulation In Intakes with Multi-block option (SSIIM) software, significant results were obtained 

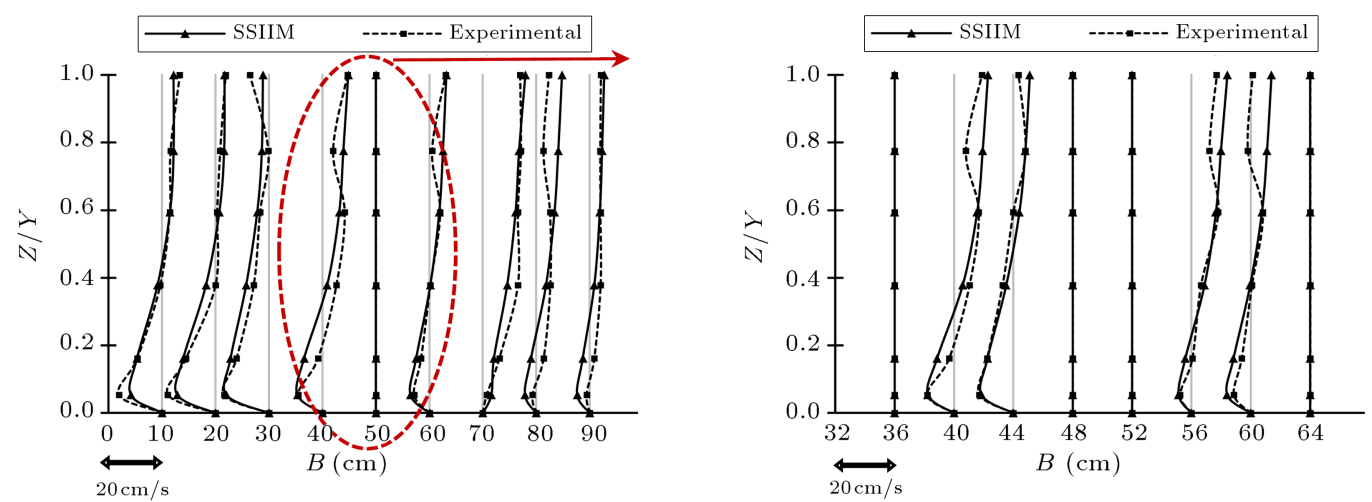

(a)
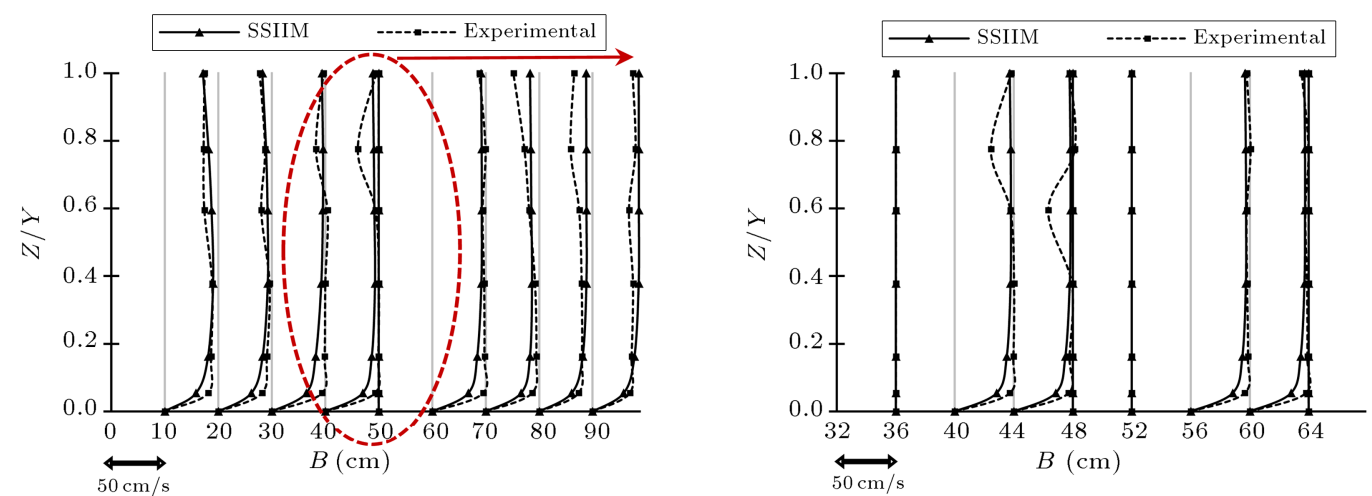

(b)
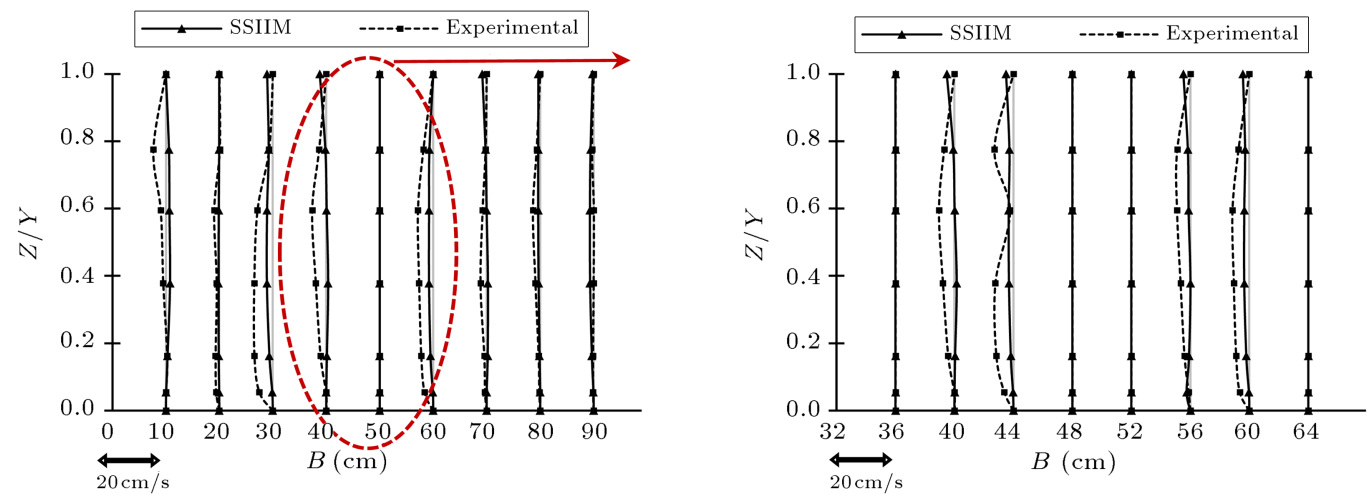

(c)

Figure 17. Typical (a) transverse, (b) longitudinal, and (c) vertical velocity profiles in the 90-degree cross-section in the numerical and experimental models at the bend with a series of piers.

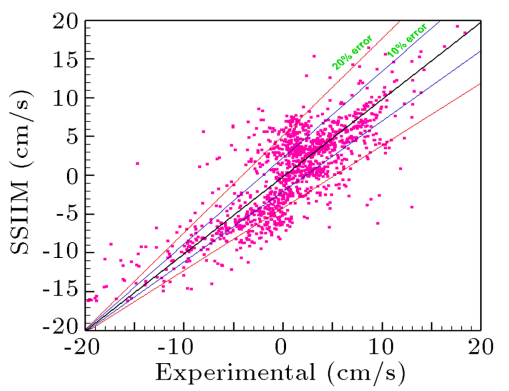

(a)

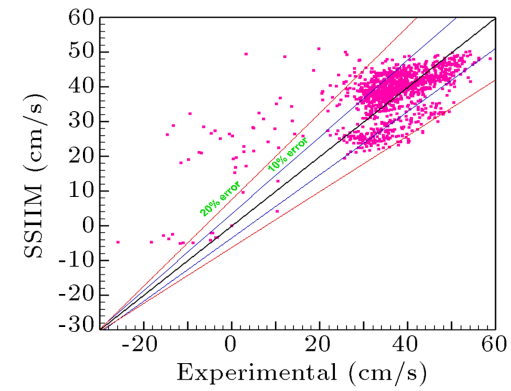

(b)

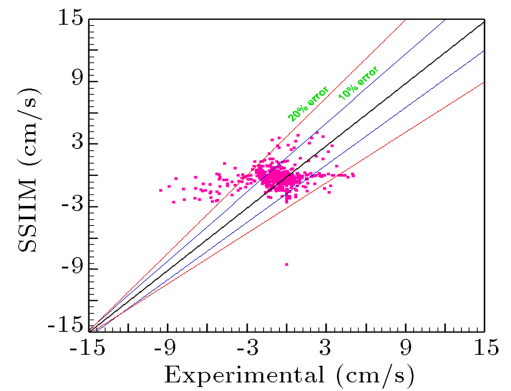

(c)

Figure 18. Comparison of (a) transvers, $U_{r}$, (b) longitudinal, $V_{\theta}$, and (c) vertical, $W_{z}$, velocity data in both numerical and experimental models at the bend with a series of piers. 


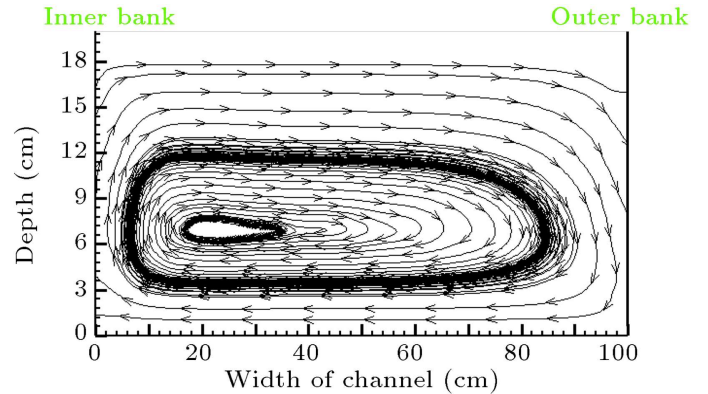

(a)

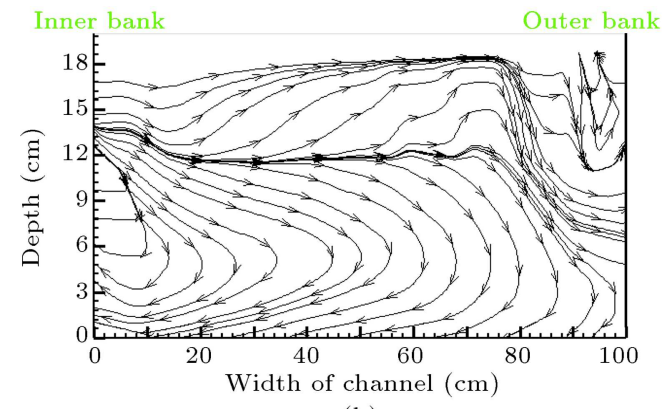

(b)

Figure 19. Typical streamlines in the 60-degree cross-section in (a) numerical and (b) experimental models at the bend with a series of piers.

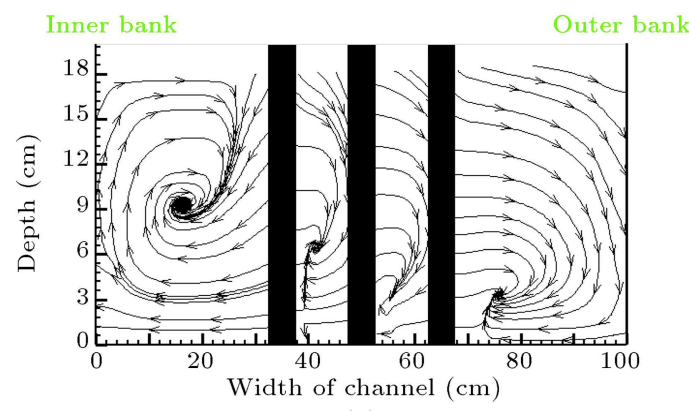

(a)

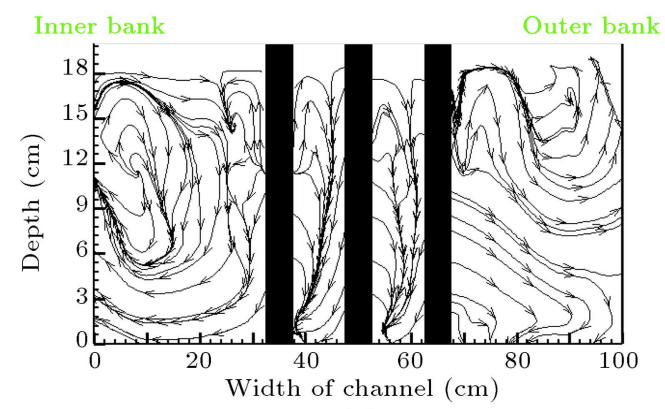

(b)

Figure 20. Typical streamlines in the 90-degree cross-section in (a) numerical and (b) experimental models at the bend with a series of piers.

indicating that SSIIM is well capable of simulating flow and scour patterns. In particular, the obtained results are given below:

1. Maximum scour and sedimentation at the bend without pier equal in both numerical and experimental models were 1.5 and $4 \%$ of the channel width, respectively;

2. 3D velocity components and flow pattern in the numerical and experimental models were quite consistent such that at the bend without pier, maximum transverse, longitudinal, and vertical velocities in both models differed only by $19 \%, 11 \%$, and $17 \%$, respectively;

3. Maximum scour and sedimentation at the bend with a single pier equal in both numerical and experimental models were 17 and $9 \mathrm{~cm}$, equal to 3.4 and 1.8 times the pier diameter, respectively;

4. At the bend with triple piers, maximum scour in the numerical model was 4.2 times the pier diameter and occurred at the center of piers location at $53 \%$ of the channel width from the inner bank of the bend. This value for the experimental model was 4 times the pier diameter and occurred at the center of piers location at $64 \%$ of the channel width from the inner bank of the bend;

5. The maximum sedimentation mound at the bend with triple piers was $12 \mathrm{~cm}$, equal to 2.4 times the pier diameter in the numerical model and occurred at a distance of 45.5 times pier diameter downstream from the pier location. This value for the experimental model was 2.5 times the pier diameter and occurred at a distance of 46.2 times pier diameter downstream from the pier location;

6. At the bend with a series of piers with the rigid bed, the percentage of errors in the $3 \mathrm{D}$ velocity components in the numerical versus experimental model was low such that maximum transverse, longitudinal, and vertical velocities only differed by $12 \%, 13 \%$, and $19 \%$, respectively;

7. There was no second secondary flow created on the water surface near the outer bank in the numerical model, while this was evidently observed in the experimental model;

8. In general, the SSIIM model satisfactorily simulated the location and value of local scour arising from single and series piers in numerical simulation of the flow and scour;

9. In the flow pattern simulation, the errors and differences are greater under moving bed conditions than rigid bed. 


\section{Nomenclature}

Depth of scour

$B$

Channel width

$Y$

Flow depth

\section{References}

1. Breusers, H.N.C. and Raudkivi, A.J. "Scouring", Hydraulic Structures Design Manual, 2, Balkema, Rotterdam (1991).

2. Nazariha, M., Design Relationships for Maximum Local Scour Depth for Bridge Pier Groups, University of Ottawa Canada (1996).

3. Blanckaert, K. and Graf, W.H. "Outer-bank cell of secondary circulation and boundary shear stress in open-channel bends", In Proc. 1st RCEM Symp., pp. 533-543, September (1999).

4. Wildhagen, J. "Applied computational fluid dynamics with sediment transport in a sharply curved meandering channel", Institute for Hydromechanics, University of Karlsruhe (TH), Germany (2004).

5. Graf, W.H. and Istiarto, I. "Flow pattern in the scour hole around a cylinder", Journal of Hydraulic Research, 40(1), pp. 13-20 (2010).

6. Masjedi, A., Bejestan, M.S., and Kazemi, H. "Effect of bridge pier position in a 180 degree flume bend on scour hole depth", Journal of Applied Sciences, 10(8), pp. 670-675 (2010).

7. Ghobadian, R. and Mohammadi, K. "Simulation of subcritical flow pattern in 180 uniform and convergent open-channel bends using SSIIM 3-D model", Water Science and Engineering, 4(3), pp. 270-283 (2011).

8. Sabita, M.S. and Maiti, P.R. "Local scouring around a circular pier in open channel", International Journal of Emerging Technology and Advanced Engineering, 2(5), pp. 454-458 (2012).

9. Ismail, Z., Jumain, M., Sidek, F., Wahab, A.K., Ibrahim, Z., and Jamal, M. "Scour investigation around single and two piers side by side arrangement", International Journal of Research in Engineering and Technology, 2(10), pp. 459-465 (2013).

10. Abdallah Mohamed, Y., Hemdan Nasr-Allah, T., Mohamed Abdel-Aal, G., and Shawky Awad, A. "Investigating the effect of curved shape of bridge abutment provided with collar on local scour, experimentally and numerically", Ain Shams Engineering Journal, 6(2), pp. 403-411 (2014).

11. Akib, S., Basser, H., Karami, H., and Jahangirzadeh, A. "Retrofitting of bridge piers against the scour damages: Case study of the marand-soofian route bridge", World Academy of Science, Engineering and
Technology, International Journal of Civil, Architectural Science and Engineering, 8, pp. 56-60 (2014).

12. Najafzadeh, M. and Barani, G.A. "Experimental study of local scour around a vertical pier in cohesive soils", Scientia Iranica, Transactions A, Civil Engineering, 21(2), p. 241 (2014).

13. Ehteram, M. and Mahdavi Meymand, A. "Numerical modeling of scour depth at side piers of the bridge", Journal of Computational and Applied Mathematics, 280, pp. 68-79 (2015).

14. Ismael, A., Gunal, M., and Hussein, H. "Effect of bridge pier position on scour reduction according to flow direction", Arabian Journal for Science and Engineering, 40(6), pp. 1579-1590 (2015).

15. Tabarestani, M.K., Zarrati, A.R., Mashahir, M.B., and Mokallaf, E. "Extent of riprap layer with different stone sizes around rectangular bridge piers with or without an attached collar", Scientia Iranica, Transactions A, Civil Engineering, 22(3), p. 709 (2015).

16. Azizi, S., Farsadizadeh, D., Arvanaghi, H., and Abbaspour, A. "Numerical simulation of flow pattern around the bridge pier with submerged vanes", Journal of Hydraulic Structures, 2(2), pp. 46-61 (2016).

17. Fael, C., Lança, R., and Cardoso, A. "Effect of pier shape and pier alignment on the equilibrium scour depth at single piers", International Journal of Sediment Research, 31(3), pp. 244-250 (2016).

18. Vaghefi, M., Ghodsian, M., and Salimi, S. "Scour formation due to laterally inclined circular pier", Arabian Journal for Science and Engineering, 41(4), pp. 13111318 (2016).

19. Vaghefi, M., Ghodsian, M., and Salimi, S. "The effect of circular bridge piers with different inclination angles toward downstream on scour", Indian Academy of Sciences, 41(1), pp. 75-86 (2016).

20. Wang, H., Tang, H., Xiao, J., Wang, Y., and Jiang, S. "Clear-water local scouring around three piers in a tandem arrangement", Science China Technological Sciences, 59(6), pp. 888-896 (2016).

21. Akbari, M. and Vaghefi, M. "Experimental investigation on streamlines in a $180^{\circ}$ sharp bend", Acta Scientiarum. Technology, 39(4), pp. 425-432 (2017).

22. Hamidi, A. and Siadatmousavi, S.M. "Numerical simulation of scour and flow field for different arrangements of two piers using SSIIM model", Ain Shams Engineering Journal, 9(4), pp. 2415-2426 (2018).

23. Karimi, N., Heidarnejad, M., and Masjedi, A. "Scour depth at inclined bridge piers along a straight path: a laboratory study", Engineering Science and Technology, an International Journal, 20(4), pp. 1302-1307 (2017). 
24. Khaple, S., Hanmaiahgari, P.R., Gaudio, R., and Dey, S. "Interference of an upstream pier on local scour at downstream piers", Acta Geophysica, 65(1), pp. 29-46 (2017).

25. Vaghefi, M., Tabibnazhad Motlagh, M.J., Hashemi, S.SH., and Moradi, S. "Experimental study of bed topography variations due to placement of a triad series of vertical piers at different positions in a $180^{\circ}$ bend", Arabian Journal of Geosciences, 11(5), p. 102 (2018).

26. Olsen, N.R.B., Jimenes, O.F., Abrahamsen, L., and Lovoll, A. "3D CFD modeling of water and sediment flow in a hydropower reservoir", International Journal of Sediment Research, 14(1), pp. 16-24 (1999).

27. Olsen, N.R.B. "A three dimensional numerical model for simulation of sediment movements in water intakes with multiblock option", Online User's Manual, 166, pp. 25-34 (2007).

28. Khajeh, S.B.M., Vaghefi, M., and Mahmoudi, A. "The scour pattern around an inclined cylindrical pier in a sharp 180-degree bend: an experimental study", International Journal of River Basin Management, 15(2), pp. 207-218 (2017).

29. Vaghefi, M., Akbari, M., and Fiouz, A.R. "An experimental study of mean and turbulent flow in a 180 degree sharp open channel bend: Secondary flow and bed shear stress", KSCE Journal of Civil Engineering, 20(4), pp. 1582-1593 (2016).

30. Vaghefi, M. and Akbari, M. "A procedure for setting up a 180-degree sharp bend flume including construction and examinations with hydraulic structures", Scientia Iranica, Transactions A, Civil Engineering, 26(6), pp. 3165-3180 (2019).
31. Tabibnejad Motlagh, M.J. "Experimental studies to determine flow and scour pattern around vertical series in a sharp 180-degree bend", M.S. Thesis, Persian Gulf university of Bushehr (2016) (In Persian).

\section{Biographies}

Morteza Asadollahi was born in Shiraz, Iran in 1993. He earned MSc degrees in Hydraulic Structures from Persian Gulf University, Bushehr, Iran in 2017. His research interests are in the areas of river engineering, hydraulic structures, and sedimentation.

Mohammad Vaghefi was born in Shiraz, Iran in 1973. He earned BSc and MSc degrees in Civil Engineering from Shiraz University, Iran in 1997 and 1999, respectively, and a $\mathrm{PhD}$ degree from Tarbiat Modares University, Tehran, Iran in 2009. He is currently the Associate Professor of Civil Engineering at Persian Gulf University, Bushehr, Iran. His areas of interest include hydraulic engineering, fluid mechanics, open channel hydraulics, river engineering, water flow engineering, hydrodynamics, and hydraulic structures. He has presented 250 papers in national and international conferences and has published 170 journal papers.

Mohammad Javad Tabibnejad Motlagh was born in Shiraz, Iran in 1989. He earned MSc degrees in hydraulic structures from Persian Gulf University, Bushehr, Iran in 2015. His research interests are in the areas of river engineering, hydraulic structures, and sedimentation. He is the author of two published paper in journals. 